\title{
KINERJA APARATUR SIPIL NEGARA DALAM PERSPEKTIF GENDER DI DIREKTORAT JENDERAL BINA PEMBANGUNAN DAERAH KEMENTERIAN DALAM NEGERI
}

\author{
Meiliawanti Ramdhani*); Khasan Effendy; Sampara Lukman \\ Pascasarjana Institut Pemerintahan Dalam Negeri Jakarta \\ *)email: meiliawantiramdhani@yahoo.com
}

Paper Accepted: 30 Juni 2021 Paper Reviewed: 01-07 Juli 2021 Paper Edited: 08-15 Juli 2021 Paper Approved: 17 Juli 2021

\begin{abstract}
ABSTRAK
Penelitian ini membahas tentang Kinerja Aparatur Sipil Negara Dalam Perspektif Gender di Direktorat Jenderal Bina Pembangunan Daerah Kementerian Dalam Negeri. Tujuan peneltian ini adalah untuk mengetahui kinerja ASN dalam perspektif gender di Direktorat Jenderal Bina Pembangunan Daerah dan kendala yang timbul pada analisis kinerja ASN dalam perspektif gender di lingkungan tersebut. Metode yang digunakan dalam penelitian ini bersifat kualitatif deskriptif dengan pengumpulan data melalui Studi Kepustakaan dan Wawancara Langsung kepada informan penelitian. Sampel ditentukan menggunakan snow ball technique yaitu dengan memperoleh 12 informan penelitian. Adapun hasil dari penelitian ini dilihat berdasarkan empat sudut pandang yang dapat disimpulkan sebagai berikut: 1) Dilihat berdasarkan sudut padang motivasi ASN Ditjen Bangda Kemedagri masih rendah; 2) Dari sudut pandang kompetensi ASN Ditjen Bangda Kemedagri masih belum adanya pemerataan; 3) Dari sudut padang regulasi yang mengatur kinerja ASN Ditjen Bangda Kemedagri penerapan telah maksimal dilakukan; 4) Dari sudut padang budaya organisasi yang berkembang dalam mendukung kinerja ASN Ditjen Bangda Kemedagri telah berkembang dengan baik. Kendala yang timbul, yaitu: 1) Kendala motivasi kurangnya perhatian pimpinan; 2) Kendala kompetensi adanya ketidaknyamanan ASN perempuan dalam bekerja; 3) Kendala regulasi yaitu pembebanan yang tidak sesuai porsi; 4) Kendala budaya organisasi yaitu anggapan bahwa ASN perempuan tidak dapat bekerja secara optimal.
\end{abstract}

Kata Kunci : Gender, Persfektif dan Kinerja.

\section{PENDAHULUAN}

Bangsa Indonesia saat ini sedang berada pada masa demokrasi dan globalisasi, dengan masa ini bangsa Indonesia tentunya tidak terlepas dari perubahan-perubahan yang terjadi khususnya pada kaum perempuan, memberikan peluang perbaikan nasib bagi kaum perempuan yang selama ini terpinggirkan. Isu kesetaraan antara laki-laki dan perempuan muncul dari menguatnya kesadaran masyarakat bahwa telah terjadi ketimpangan antara laki-laki dan perempuan pada penyelenggaraan kehidupan bersama. Upaya peningkatan kedudukan, peran, dan kualitas perempuan, serta upaya mewujudkan kesetaraan dan keadilan gender dalam kehidupan berkeluarga, bermasyarakat, berbangsa dan bernegara sementara ini belum optimal agar potensi yang ada pada kaum perempuan dapat bermanfaat secara optimal, agar perempuan memiliki akses yang sama dengan laki-laki, perlu diciptakan situasi yang dapat 16 mendorong perempuan melakukan 
aktivitasnya sesuai kemampuan yang ada pada dirinya sendiri.

Undang-Undang Dasar 1945 sudah memberi penegasan bahwa setiap warga negara (laki-laki dan perempuan) memiliki hak dan kewajiban yang sama dalam kegiatan pembangunan. Peran dan kedudukan perempuan dalam pembangunan mulai mendapat perhatian serius dari pemerintah dengan dimasukkannya isu perempuan dalam Garis- garis Besar Haluan Negara (GBHN) tahun 1978.

Pegawai Negeri Sipil adalah sumber daya manusia yang dimiliki oleh organisasi pemerintah yang digunakan untuk menggerakkan atau mengelola sumber daya lainnya sehingga harus benar-benar dapat digunakan secara efektif dan efisien sesuai kebutuhan riil organisasi yang telah memenuhi syarat yang ditentukan, diangkat oleh pejabat yang berwenang dan diserahi tugas dalam suatu jabatan negeri, atau diserahi tugas negara lainnya, dan digaji berdasarkan peraturan perundangundangan yang berlaku. Di dalam Undang-Undang Republik Indonesia Nomor 5 Tahun 2014 tentang Aparatur Sipil Negara pasal 72 ayat 1 diamanatkan bahwa promosi Pegawai Negeri Sipil dilakukan berdasarkan perbandingan objektif antara kompetensi, kualifikasi, dan persyaratan yang dibutuhkan oleh jabatan, penilaian atas prestasi kerja, kepemimpinan, kerjasama, kreativitas, dan pertimbangan dari tim penilai 17 kinerja PNS pada instansi pemerintah, tanpa membedakan gender, suku, agama, ras, dan golongan. Namun pada kenyataannya, fakta di lapangan menunjukkan belum sepenuhnya reformasi birokrasi dalam hal penempatan aparatur Pegawai Negeri Sipil menerapkan prinsipprinsip tersebut.

Pengangkatan Pegawai Negeri Sipil dalam suatu jabatan dilaksanakan berdasarkan prinsip profesionalisme sesuai dengan kompetisi, prestasi kerja, dan jenjang pangkat yang ditetapkan untuk jabatan itu serta syarat objektif lainnya tanpa 18 membedakan jenis kelamin, suku, agama, ras dan golongan. Tujuan pengangkatan pegawai negeri sipil dalam jabatan struktural adalah mewujudkan aparatur negara yang berdaya guna dan berhasil guna serta sanggup dan mampu melaksanakan tugastugas dengan sebaik-baiknya. Di lingkungan Direktorat Jenderal Bina Pembangunan Daerah peranan perempuan masih tertinggal di berbagai bidang dilingkungan birokrasi dibandingkan dengan kaum laki-laki. Ditjen Bina Pembangunan Daerah Kementerian Dalam Negeri terkesan kurang percaya untuk menempatkan posisi dalam pengambilan keputusan, padahal kaum perempuan cukup berpotensi dalam berbagai bidang kehidupan. Hal ini diperlihatkan posisi pimpinan pada jabatan struktural eselon, bahwa posisi ini 19 banyak dipegang oleh kaum laki-laki

\section{Identifikasi Masalah}

Kinerja dapat diartikan sebagai gambaran mengenai tingkat pencapaian pelaksanaan suatu kegiatan, program atau kebijakan dalam mewujudkan sasaran, tujuan, misi, dan visi organisasi yang tetuang dalam rencana strategi suatu organisasi. Dari latar belakang masalah yang telah diuraikan, maka dapat diidentifikasi permasalahan sebagai berikut :

1. Belum optimalnya motivasi ASN dalam menyikapi perbedaan Gender

2. Rendahnya pemahaman dalam menyikapi Perspektif Gender pada ASN Ditjen Bina Pembangunan Daerah Kementerian Dalam Negeri

3. Masih rendahnya kompetensi ASN Perempuan dalam menyeimbangkan kesetaraan gender

4. Kurangnya kesempatan yang diberikan pimpinan pada Ditjen Bina Pembangunan Daerah kepada ASN perempuan

\section{Pembatasan Penelitian}

Pembatasan masalah penelitian dibatasi hanya pada analisis 21 Kinerja Aparatur Sipil Negara Dalam Perspektif Gender di Direktorat Jenderal Bina Pembangunan Daerah Kementerian Dalam Negeri.

\section{Rumusan Masalah}

Berdasarkan identifikasi dan pembatasan masalah diatas, maka reseacrh question yang diajukan untuk memperjelas pembahasan dalam penelitian ini dapat dirumuskan sebagai berikut:

1. Bagaimana kinerja ASN dalam Perspektif gender di Direktorat Jenderal Bina Pembangunan Daerah?

2. Kendala apa saja yang timbul pada analisis kinerja ASN dalam Perspektif gender di lingkungan Direktorat Jenderal Bina Pembangunan Daerah?

\section{Maksud dan Tujuan Penelitian}

Dengan rumusan masalah tersebut, maka penelitian ini bertujuan adalah:

1. Menganalisis kinerja ASN dalam Perspektif gender di Direktorat Jenderal Bina Pembangunan Daerah

2. Menganalisis kendala yang disinyalir akan timbul pada analisis kinerja ASN 
dalam Perspektif gender di lingkungan Direktorat Jenderal Bina Pembangunan Daerah.

\section{Kegunaan Penelitian \\ Kegunaan Praktis}

Bagi Pimpinan Ditjen Bina Pembangunan Daerah, hasil penelitian kiranya dapat diterima sebagai masukan yang bermanfaat yaitu:

1. Untuk mengoptimalkan fungsi keterwakilan kaum perempuan di Ditjen Bina Pembangunan Daerah dan sekaligus mengefektifkan implementasi kebijakan pengarusutamaan gender dalam pelaksanaan tugas dan fungsi Ditjen Bina Pembangunan Daerah

2. Bagi ASN Perempuan yang bertugas di Ditjen Bina Pembangunan Daerah, hasil penelitian diharapkan kiranya dapat dijadikan rujukan untuk memperjuangkan kesetaraan dan keadilan gender melalui perencanaan dan pelaksanaan pembangunan nasional

3. Bagi para pihak yang berkepentingan dengan hasil penelitian, diharapkan hasil penelitian dapat dijadikan acuan actual untuk mengkritisi fenomena kesetaraan dan keadilan gender di Indonesia.

\section{Kegunaan Teoritis}

Hasil penelitian diharapkan kiranya dapat dijadikan acuan studi oleh para peneliti untuk mengembangkan konsep-konsep penelitian yang lebih mendalam dan menyeluruh terhadap fenomena kinerja dalam Perspektif gender dalam pelaksanaan tugas dan fungsi Ditjen Bina Pembangunan Daerah. Lebih dari itu, hasil penelitian juga diharapkan dapat dijadikan kontribusi bagi pengembangan ilmu pengetahuan, terutama pengembangan Ilmu Pemerintahan yang semakin fungsional untuk mengkritisi penyelenggaraan pemerintahan oleh lembaga-lembaga pemerintahan

\section{Kajian Pustaka}

Kajian pustaka merupakan pola untuk mengarahkan peneliti dalam membentuk kategori substantif. Kajian kepustakaan sangat diperlukan guna memberi landasan 15 dalam penelitian untuk menjawab rumusan masalah penelitian sejak awal. Fungsifungsi pemerintahan sebagaimana diungkapkan oleh Rasyid bahwa terdapat tiga fungsi hakiki pemerintahan yakni fungsi pembangunan, pemberdayaan dan fungsi pelayanan(Rasyid, 1996).

\section{Konsep Ilmu Pemerintahan}

Ilmu pemerintahan adalah ilmu yang mempelajari tentang cara pengaturan lembagalembaga publik dan bagaimana lembagalembaga itu difungsikan, baik yang bersifat intern, maupun ekstern yang ditunjukan untuk kepentingan warga. Pendekatan materi disiplin merupakan karakter utama dari ilmu pemerintahan dalam menelaah gejala pemerintahan. Pendekatan ini lahir sebagai penyempurnaan dari pendekatan interdisiplin yang sebelumnya dipergunakan

\section{Konsep Administrasi Pemerintahan}

Menurut Siagian (2004 : 2-3) administrasi adalah "keseluruhan proses kerja antara dua orang manusia atau lebih yang didasarkan atas rasionalitas tertentu untuk mencapai tujuan yang telah ditentukan sebelumnya". Ada beberapa hal hal yang terkandung dalam definisi tersebut, antara lain : Pertama, administrasi sebagai seni adalah suatu proses yang diketahui hanya permulaannya sedang akhirnya tidak diketahui; Kedua, administrasi mempunyai unsur-unsur tertentu, yaitu adanya dua manusia atau lebih, adanya tujuan yang hendak dicapai, adanya tugas atau tugas-tugas yang harus dilaksanakan, adanya peralatan dan perlengkapan untuk melaksanakan tugas-tugas itu. Ke dalam golongan peralatan dan perlengkapan termasuk pula waktu, tempat, peralatan materi serta sarana lainnya; Ketiga, bahwa administrasi sebagai proses kerja sama bukan merupakan hal yang baru karena ia telah timbul bersama-sama dengan timbulnya peradaban manusia. Tegasnya, administrasi sebagai seni merupakan suatu fenomena sosial

Dengan sendirinya antar manusia, kerjasama, kegiatan, sarana dan tujuan tersebut saling berkaitan satu sama lain. Oleh karena itu, administrasi merupakan suatu sistem dan kelima hal tersebut merupakan sub sistemnya. Sebagai suatu sistem, administrasi merupakan sistem yang bersifat :

1. Abstrak, karena tidak dapat dikenali wujud rupanya

2. Buatan manusia (man-made systems)

3. Terbuka (open-systems), karena peka terhadap pengaruh lingkungan, baik sosial maupun fisik

4. Hidup (living systems), berkembang terus akibat sifat terbukanya

5. Kompleks, karena didalamnya terdapat banyak terjadi hubungan antar subsistem yang satu dengan yang 
lainnya, disamping sistem administrasi sebagai suatu totalitas juga berinteraksi dengan sistem-sistem lainnya.

\section{Konsep Dasar Kerja}

Perspektif Kinerja Gender Aparatur Sipil

Negara pada Direktorat Bina Jenderal Pembangunan Daerah Kementerian Dalam Negeri tampak menjadi suatu kondisi dinamis pelaksanaan tugas dan fungsi kerja birokrasi. Kondisi dinamis ini terungkap dari konsep, proses dan hasil kerja.

\section{Konsep Dasar Kinerja}

Kinerja adalah suatu hasil kerja yang dapat dicapai oleh seseorang atau kelompok orang dalam suatu organisasi, sesuai dengan wewenang dan tanggungjawab masing-masing, dalam rangka upaya mencapai tujuan organisasi bersangkutan secara legal, tidak melanggar hukum dan sesuai dengan moral maupun etika. Kinerja adalah penampilan suatu proses kerja dalam organisasi yang meliputi perilaku para pelakunya (atasan dan bawahan, pegawai/pekerja), proses pekerjaan serta hasil pekerjaan yang dicapai. Prawirosentono (1997:1-2). Kinerja tidak hanya mencakup ukuran kualitas pelaksanaan tugas atau pekerjaan dan ukuran kuantitas pelaksanaan tugas atau pekerjaan; namun mencakup pula bagaimana kerja itu dilaksanakan. Kuantitas dan kualitas kinerja yang dimaksud mencakup kinerja individu dan kinerja kelompok atau unit kerja. Ukuranukuran kinerja yang demikian itu dapat dikatakan produktif, efektif dan efisien bila sesuai dengan fungsi jabatan atau fungsi pekerjaan masing-masing individu atau unit kerja

\section{Penilaian Kinerja}

Menurut Yaslis (2002: 88), penilaian kinerja dapat didefinisikan sebagai proses formal yang dilakukan untuk mengevaluasi tingkat pelaksanaan pekerjaan atau unjuk kerja (performance appraisal) seorang personel dan memberikan umpan balik untuk kesesuaian tingkat kinerja. Untuk dapat mengetahui kinerja individu, kelompok atau organisasi diperlukan suatu pendekatan penilaian kinerja. Penilaian kinerja adalah proses menilai hasil karya personel dalam suatu organisasi melalui instrumen penilaian kinerja. Pada hakikatnya, penilaian kinerja merupakan suatu evaluasi terhadap penampilan kerja personel dengan membandingkannya dengan standar baku penampilan. Kegiatan penilaian kinerja ini membantu pengambilan keputusan bagian personalia dan memberikan umpan balik kepada para personel tentang pelaksanaan kerja mereka. (Yaslis, 2002: 87)

\section{Peningkatan Kinerja}

Setelah melalui proses penilaian kinerja, dan diketahui adanya kelemahan kinerja, maka langkah sleanjutnya adalah melakukan upaya peningkatan kinerja. Peningkatan kinerja hingga ke tingkat yang profesional sesuai dengan bidang tugasnya merupakan suatu tuntutan manajemen kinerja yang perlu dikembangkan di setiap organisasi. Mengapa dengan demikian, karena menurut Gilley et al 36 (2000:283) organisasi gagal untuk mencapai hasil kinerja yang diinginkan karena berbagai alasan, oleh sebab itu perlu dilakukan upaya peningkatan kinerja.

\section{Faktor-faktor yang Mempengaruhi Kinerja}

Siagian (2002:168-169) mengatakan bahwa kinerja seseorang ditentukan oleh tiga faktor utama sebagaimana yang dikemukakan berikut ini:

1. Motivasi. Yang dimaksud dengan motivasi ialah daya dorong yang dimiliki, baik secara intrinsik maupun ekstrinsik, yang membuatnya mau dan rela untuk bekerja sekuat tenaga dengan mengerahkan segala kemampuan yang ada demi keberhasilan organisasi dalam mencapai tujuan dan berbagai sasaranya. Keberhasilan organisasional tersebut memungkinkan yang bersangkutan untuk mencapai tujuan pribadinya berupa harapan, keinginan, cita-cita, dan berbagai jenis kebutuhannya.

2. Kemampuan. Adanya kemampuan yang bersifat fisik dan ini lebih diperlukan oleh karyawan yang dalam pelaksanaan tugasnya lebih banyak menggunakan otot. Di lain pihak, ada kemampuan yang bersifat mental intelektual, yang lebih banyak dituntut oleh penyelesaian tugas pekerjaan dengan menggunakan otak. Sudah barang tentu mereka yang lebih banyak menggunakan otot tetap harus menggunakan otak dan 43 sebaliknya, mereka yang lebih banyak menggunakan otak, tetap dituntut memiliki kemampuan fisik.

3. Ketepatan penugasan. Dalam dunia manajemen ada ungkapan yang mengatakan bahwa,'tidak ada karyawan yang bodoh, yang bodoh 
adalah para manajer yang tidak mengenali secara tepat pengetahuan, keterampilan, kemampuan, bakat, dan minat para bawahannya."Memang telah terbukti, bahwa dengan penempatan yang tidak tepat, kinerja seseorang tidak sesuai dengan harapan manajemen dan tuntutan organisasi; dengan demikian, mereka menampilkan produktivitas kerja yang rendah. Karena itu, seorang manajer perlu berpegang pada rumus berikut :

$$
\mathrm{P}=\mathrm{M} \times \mathrm{K} \times \mathrm{T}
$$

Dimana $\mathrm{P}$ adalah performance atau kinerja, $\mathrm{M}$ adalah Motivasi, $\mathrm{K}$ adalah Kemampuan, dan $\mathrm{T}$ adalah Tugas yang tepat. Itulah sebabnya, dalam manajemen sumber daya manusia terdapat rumus : The right man in the right place, doing thenright job at the right time, and getting the right pay. Terjemahan bebasnya ialah : Penempatan orang yang tepat pada tugas yang tepat pada waktu yang tepat dan memperoleh imbalan yang tepat pula

\section{Konsep Dasar Manajemen Sumber Daya Manusia}

Menurut United Nation Development Programme (UNDP) tahun 1990, pembangunan manusia baik di tingkat global, tingkat nasional maupun daerah ditekankan pada pembangunan yang berpusat pada manusia yang menempatkan manusia sebagai tujuan akhir dari pembangunan dan bukan sebagai alat pembangunan. Berbeda dengan konsep pembangunan yang mengutamakan pertumbuhan ekonomi, dengan asumsi bahwa pertumbuhan ekonomi pada akhirnya akan menguntungkan manusia, Di sini pembangunan manusia memperkenalkan konsep yang lebih luas dan lebih komprehensif yang mencakup semua pilihan yang 47 dimiliki oleh manusia di semua golongan masyarakat pada semua tahap pembangunan.

Proses manajemen sumber daya manusia yang akan dibahas (Pigors dan Myers, 1961:17) yaitu menekankan pada : recruitment (pengadaan), maintenance (pemeliharaan) dan development (pengembangan).

\section{Birokrasi}

Dalam satu negara semua pihak bersepakat bahwa diperlukan birokrasi karena suatu negara mempunyai masyarakat yang perlu diatur. Oleh karena suatu negara tanpa pemerintahan atau birokrasi adalah sebuah kekacauan massal, dalam artian tanpa suatu birokrasi kecenderungan terjadinya perselisihan konflik. Fenomena pemerintahan modern, ditandai oleh terjadinya berbagai peraturan perundangan yang merujuk pada semua segi antar hubungan dalam kehidupan masyarakat sehingga ketertiban, ketentraman, kedamaian dan kesejahteraan dapat dilaksanakan.

Nugraha (2007:180) menjelaskan bahwa Birokrasi ialah alat kekuasaan bagi yang menguasainya, dimana para pejabatnya secara bersama-sama berkepentingan dalam kontinuitasnya. Weber memandang birokrasi sebagai arti umum, luas, serta merupakan tipe birokrasi yang rasional. Weber berpendapat bahwa tidak mungkin kita memahami setiap gejala kehidupan yang ada secara keseluruhan, sebab yang mampu kita lakukan hanyalah memahami sebagian dari gejala tersebut. Satu hal yang penting ialah memahami mengapa birokrasi itu bisa diterapkan dalam kondisi organisasi negara tertentu. Dengan demikian tipe ideal memberikan penjelasan kepada kita bahwa kita mengabstraksikan aspek-aspek yang amat penting yang membedakan antara kondisi organisasi tertentu dengan lainnya (Thoha, 2005:16).

\section{Fungsi Pelayanan dan Pengaturan}

Dalam negara administratif, pemerintah dan seluruh jajarannya dikenal sebagai abdi masyarakat dalam pemberian berbagai jenis pelayanan yang 54 diperlukan oleh seluruh warga masyarakat. Keseluruhan jajaran pemerintahan negara merupakan satuan birokrasi pemerintahan yang juga dikenal dengan istilah civil service. Pemerintah beserta seluruh jajaran aparatur birokrasi bukanlah satusatunya pihak yang bertanggung jawab untuk menyelenggarakan berbagai kegiatan pembangunan nasional, tetapi merupakan kenyataan bahwa peranan pemerintah dan jajarannya bersifat dominan. Diantaranya berbagai satuan kerja yang terdapat dalam lingkungan pemerintahan, terdapat pembagian tugas yang pada umumnya didasarkan pada prinsip fungsionalisasi (Sinambela, 2006:63)

\section{Konsep Peran Birokrasi}

Nilai dan prinsip merupakan komitmen dan melekat pada setiap individu dan institusi sesuai posisi dan peran masing-masing dalam kehidupan bernegara. Dalam pembangunan birokrasi, fungsi dari nilai-nilai tersebut adalah menjadi pedoman perilaku dalam bersikap, berpikir, dan bertindak, baik secara individual 
maupun secara institusional, yang dalam rangka pelaksanaan tugas dan fungsi kepemerintahan dapat dijabarkan antara lain dalam format "pengelolaan pelayanan dan kebijakan prima" (excellent management of public services and policies) yang memungkinkan karya dan kinerja keseluruhan pilar dan unsur masyarakat madani mencapai tingkat optimalitas sosial. Tanpa consensus, kompetensi, dan komitmen bersama, tidak mungkin dapat terwujud sebagai sistem penyelenggaraan negara dan pembangunan bangsa yang baik.

\section{Konsep Gender}

Sasaran utama pembangunan yang berspektif gender adalah memberdayakan perempuan dengan meningkatkan sumber daya manusia perempuan itu sendiri, dengan kemampuan dan keamanan untuk memiliki rasa tanggung jawab kemasyarakatan terpadu dan harmonis antar sektor dan sub sektor pemerintahan, organisasi, kemasyarakatan dan politik. Pemberdayaan perempuan dilakukan untuk menunjang dan mempercepat tercapainya kualitas hidup dan mitra kesejajaran laki-laki dan perempuan, dilaksanakan melalui kegiatan sosialisasi/advokasi pendidikan dan latihan bagi kaum perempuan yang bergerak dalam bidang atau sektor. Dengan berbagai sosialisasi pendidikan dan latihan yang difokuskan kepada perempuan tentunya terdapat variasi pengetahuan dan pengalaman yang dapat memacu kemauan danuntuk menerobos arus yang menjadi penghambat maju sejajar dengan mitra kerjanya yaitu kaum laki-laki.

\section{Perspektif Gender}

Gender adalah pembedaan peran, status, pembagian kerja yang dibuat oleh sebuah masyarakat berdasarkan jenis kelamin. (Simatauw dkk, 2001:7) Gender adalah seperangkat peran yang, seperti halnya kostum dan topeng di teater, menyampaikan kepada orang lain bahwa kita adalah feminin atau maskulin. Perangkat perilaku khusus ini-yang mencakup penampilan, pakaian, sikap, kepribadian, bekerja di dalam dan di luar rumah tangga, seksualitas, tanggungjawab keluarga dan sebagainya-secara bersama-sama memoles "peran gender kita. (Mosse, 2002:2-3) Gender berbeda dengan jenis kelamin (sex). Gender adalah bentukan manusia bukan kodrat, yang artinya dapat berubah setiap saat. Laki-laki memiliki penis dan perempuan memiliki vagina adalah kodrat. Perempuan haid dan melahirkan adalah kodrat yang tidak dapat dirubah oleh manusia. Analisa gender menganalisa hubungan-hubungan kuasa dan peran antara laki-laki dan perempuan dalam kehidupan manusia. Melalui analisa gender kita dapat menelaah ketidak adilan antara laki-laki dan prempuan yang disebabkan oleh bangunan peradaban dan kebudayaan manusia. (Simatauw dkk, $2001: 8-9$ )

\section{METODE PENELITIAN}

Penelitian ini dilakukan dengan pendekatan penelitian kualitatif untuk mengungkap dan membahas Kinerja ASN dalam Persfektif Gender pada Ditjen Bina Pembangunan Daerah. Penelitian ini merupakan kegiatan "observed facts" yang menghasilkan "knowledge based on experience".

Selanjutnya, pendekatan penelitian kualitatif dipilih dengan alasan-alasan sebagai berikut: Pertama, penelitian kualitatif merupakan pendekatan penelitian yang menonjolkan penggalian obyek dan subyek permasalahan secara mendalam dan dinamis untuk mengungkap berbagai aspek yang tercakup dalam obyektivitas Kinerja ASN dalam Persfektif Gender pada Ditjen Bina Pembangunan Daerah menurut arena kajian yang dirancang dengan pendekatan model Kinerja dari Sluyter.

Kedua, penelitian kualitatif dipilih dengan alasan bahwa penelitian kualitatif dapat mengungkap fenomena sosial yang terbentuk dari situasi dan kondisi tertentu secara mendalam dan dinamis melalui mediasi data primer yang diperoleh dari para pihak yang dipandang sama-sama memahami dan merasakan secara langsung situasi dan kondisi dinamis obyek yang diteliti namun menunjukkan juga perbedaan sudut pandang dan penafsiran terhadap situasi dan kondisi dinamis masalah yang memungkinkan pengungkapan dan pembahasan obyek penelitian menjadi heuristik dan empirik.

Teknik pengumpulan data yang digunakan antara lain adalah; pengamatan; wawancara; dan dokumentasi.

\section{HASIL DAN PEMBAHASAN}

\section{Kinerja Aparatur Sipil Negara Dalam Perspektif Gender di Direktorat Jenderal Bina Pembangunan Daerah Kementerian Dalam Negeri}

Konsep yang dikembangkan oleh Sluyter (1998:14), terdapat dua kondisi yang memperngaruhi kinerja dalam sebuah organisasi, yakni faktor yang langsung bersentuhan (faktor internal) dan faktor yang 
tidak secara langsung bersentuhan (faktor eksternal). Dengan demikian kompetensi dan motivasi merupakan faktor internal yang mempengaruhi kinerja organisasi, dan sifatnya melekat pada individu pekerja atau personil. Sedangkan faktor yang secara tidak langsung bersentuhan dengan kinerja organisasi berupa regulasi dan budaya organisasi karena faktor ini sifatnya datang dari luar dan mempengaruhi personil organisasi, dan pada gilirannya berpengaruh juga pada kinerja organisasi.

\section{Analisis Motivasi Aparatur Sipil Negara Dalam Perpektif Gender}

Uraian yang merujuk pada motivasi kerja Aparatur Sipil Negara di Ditjen Bina Pembangunan Daerah Kementerian Dalam Negeri (Ditjen Bangda Kemendagri) dalam perspektif gender tentunya membutuhkan kejelasan arah dalam mengoprasionalkan semua elemen motivasi yang timbul pada setiap diri ASN Ditjen Bangda Kemendagri. Dalam kontek ini pola pertanyaan yang timbul adalah sikap pengabdian yang seperti apakah yang harus diperlihatkan oleh ASN untuk menyikapi peningkatan kinerja dalam perspektif gender. Pengabdian yang ditunjukkan berupa hasil akhir dalam penyelesaian tugas dengan penuh tanggung jawab dan disiplin merupakan perwujudan gambaran kinerja yang optimal. Sehingga dengan bentuk pengabdian tersebut perbedaan gender tidak dapat terlihat mencolok karena masing-masing atau tiap-tiap ASN Ditjen Bangda Kemendagri terus berupaya menselaraskan kinerja tanpa memandang perbedaan gender. Sehingga dengan cerminan hal tersebut bahwa dapat dikemukakan kinerja ASN perlu adanya sinergitas antara peraturan dan ketetapan yang berlaku untuk menjadikan ASN bekerja lebih efektif dan efisien.

Pengabdian yang merefleksikan perwujudan akan kinerja ASN dalam menyikapi perspektif gender dengan mengedepankan rasa tanggungjawab, loyalitas, efektif dan efisien serta kepatuhan pada setiap aturan dan peraturan yang telah dicanangkan untuk setiap pekerjaan atau tugas yang diamanatkan. Sehingga dengan hal tersebut bahwa dapat diharapkan terwujud sebuah kinerja yang optimal tanpa adanya perbedaan yang melihat gender baik itu laki-laki atau perempuan. Pendapat ini menjelaskan bahwa semua ASN telah mendapatkan "porsi" pekerjaan yang telah sesuai dengan tanggungjawab masing-masing tanpa melihat perbedaan gender.

\section{Analisis Kompetensi Aparatur Sipil Negara Berdasarkan Perpektif Gender}

Kompetensi yang dipandang sebagai kemampuan dan keterampilan individu diharapkan dapat sebagai tolak ukur memandang sebuah kinerja. Namun, kompetensi yang dimiliki setiap individu sangatlah berbeda dalam hal kemampuan dan pengetahuan, sehingga pandangan akan kompetensi yang dimiliki individu dapat dipandang sebagai kemampuan inteletual ASN bukan dipandang dalam perspektif gender atau jenis kelamin. Peluang atau kesempatan yang diberikan untuk pengembangan diri merupakan kebutuhan atau kepentingan semua pihak. Tanpa memandang level atau tingkatan serta jabatan dan yang terpenting tanpa memandang gender bahwa kesempatan untuk mengaktualisasikan diri dan mengembangkan kemampuan dan keterampilan manajemen diri dimiliki oleh semua pihak baik dari golongan staf terbawah maupun sampai unsur pimpinan pada unit kerja atau kelompok kerja

Secara personal pengembangan diri setiap ASN perlu mendapat dukungan dari berbagai pihak terutama dari pimpinan tertinggi yang dapat dengan bijak memeberikan rekomendasi kepada ASN yang hendak mengembangkan diri terutama dalam intelektual pendidikan. Selain pengembangan diri dalam keahlian manajerial, ASN perempuan pun harus memiliki kemampuan keahlian dalam administrasi. Dimana keahlian administrasi diharapkan dapat memberikan dukungan bagi para ASN perempuan untuk membuktikan kemampuan masing-masing. Kemampuan akan keahlian administrasi guna mendukung kinerja ASN terutama sebagai ASN Perempuan merupakan sebagai ajang pembuktian pengembangan diri pada kemampuan yang dimiliki

Pemberian rekomendasi kepada setiap ASN untuk dapat mengembangkan diri, sangat perlu mendapatkan dukungan dari berbagai pihak, terutama pihak pemberi kebijakan dalam peningkatan kapasitas diri ASN. Hal ini tanpa memandang dari perspektif gender, sehingga kesetaraan tersebut menjadi terlihat aktualisasinya. Persamaan hak akan pengembangan diri pada kemampuan atau keahlian khusus bagi ASN tanpa memandang gender atau jenis kelamin. Diharapkan menjadi sebuah titik cerah terbukanya kinerja yang lebih baik lagi dalam menjaga dan menjadikan Ditjen Bina Pembangunan Daerah Kementerian Dalam Negeri untuk terus memperhatikan dan menjaga stabilitas iklim kerja yang lebih kondusif lagi. 
Analisis Regulasi Aparatur Sipil Negara Berdasarkan Perpektif Gender

Selain faktor internal yang menyentuh langsung kepada ASN, terdapat faktor eksternal atau faktor diluar kemampuan ASN dalam peningkatan kinerja setiap ASN. Terutama dalam hal mendukung kinerja ASN dalam perspektif gender. Dengan kebijakan atau regulasi yang kuat dalam penetapan kinerja berdarakan kacamata gender diharapkan kesetaraan dan keadilan dapat tercipta dengan baik dan tetap konsisten. Harapan besar penerbitan setiap regulasi yang ada dapat memberikan perlindungan secara hukum untuk setiap ASN serta mengakomidir untuk kepentingan ASN semua tanpa mempertimbangkan sudut pandang gender. Regulasi yang dipandang sebgai wadah atau payung sebgai ASN berpijak untuk mewujudkan kinerja yang lebih baik lagi, belum mampu menjawab permasalahan yang ada. Kesetaraan dan keadilan terhadap gender merupakan sebuah hal yang perlu mendapat perhatian khusus dalam menjaga stabilitas kinerja pada semua pihak. Dengan tidak memandang prinsip perbedaan gender diharapakan dapat memperbaiki dan meningkatkan kinerja semua. Penempatan pada setiap posisi pucuk pimpinan dan yang efektif diharapkan dapat dilakukan oleh pengambil keputusan dengan cara yang objektif, semisal yang telah dilakukan dengan mengacu pada peraturan yang berlaku. Hak ini memungkinkan terbukanya peluang bagi ASN tanpa memperhatikan perspektif gender dapat berkembang dan berpartisipasi dalam pemikiran yang lebih baik lagi

$\begin{array}{ccr}\text { Ditjen Bina Pembangunan } & \text { Daerah } \\ \text { Kementerian } & \text { Dalam Negeri }\end{array}$
perjalanannya menuju sebuah unit kerja atau kelompok kerja perlu mempertahankan semangat ASN tanpa memandang sudut pandang gender. Hal ini tlah dilakukan dengan baik namun perlu adanya beberapa pertimbangan untuk terus diperbaiki seperti keterbukaan terhadap seleksi jabatan yang hendak pikul oleh ASN bergender perempuan, sehingga dengan keterbukan tersebut dapat membentuk perspektif gender di Ditjen Bina Pembangunan Daerah Kementerian Dalam Negeri telah terukir dengan optimal. Regulasi yang telah diterapkan hendaknya perlu berkesinambungan dalam penerapan dan implementasinya serta yang tak luput dari perhatian juga harus adanya evaluasi dari kebijakan atau regulasi yang diterapkan. Harapan evaluasi yang berkesinambungan pada penilaian kinerja terus dilontarkan para ASN.
Karena dengan evaluasi yang berkesinambungan tersebut dapat memperlihatkan ketepatan sasaran segala bentuk kebijakan dan peraturan serta regulasi yang telah diterapkan pada Ditjen Bina Pembangungan Daerah Kementerian Daerah. Namun, eavaluasi tersebut juga hendaknya tanpa didasari perbedaan gender

Kebersinambungan evaluasi yang diberlakuan oleh Ditjen Bangda Kemendagri diharapkan terus dapat dilakukan. Harapan ini terus digulirkan seiring dengan berkembangnya dan meningkatkanya kinerja ASN dalam melaksanakan tugas yang telah dibeikan. Kinerja ASN tanpa adanya sudut pandang perspektif gender di Ditjen Bangda Kemendagri merupakan perwujudan nyata dukungan organisasi dalam mendukung kinerja semua ASN serta membuktikan bahwa dukungan organisasi dan para pimpinan dalam mendukung kesetaraan dan keadilan gender dalam segala golongan dan tingkatan.

\section{Analisis Budaya Organisasi Aparatur Sipil Negara Dalam Perpektif Gender}

Pelaksanaan pelimpahan wewenang dalam menudukung kinerja dalam perspektif gender di Ditjen Bina Pembangunan Daerah Kemneterian Dalam Negeri terus dikembangkan dan diharapakan tersu dapat berjalan sesuai dengan kapasitas dan komposisi sumber daya yang ada. Budaya organisasi yang berkembang pada Ditjen Bangda Kemendagri guna mendukung kinerja dalam perpektif gender, mengendepankan pentingnya kerjasama antar tim serta individu. Karena dengan kerjasama yang solid antar individu dapat berkembang pada kerjasama kelompok dalam Ditjen Bangda Kemendagri, bahkan dapat disinyalir hinga kerjasama dengan kelompok kerja atau unit kerja yang ada pada Kementerian Dalam Negeri. Pentingnya kerjasama antar individu tentunya sudah memiliki aturan dan tata cara mekanisme tersendiri.

Regulasi yang tercipta dan berkembang, terus digaungkan oleh para pimpinan sehingga kesetaraan dan keadilan kinerja dalam perspektif gender dapat terus terakomodir dengan baik. Hal tersebut telah tertuang dalam peraturan Peraturan Menteri PPPA yang telah diimplementasikan pada Ditjen Bangda Kemendageri. Namun, hal tersebut belum sepenuhnya menyentuh ASN dalam hal standar operasional prosedur (SOP) pelaksaannya. Pentingnya akan sosialisasi regulasi akan kesetaraan gender di dunia kerja maupun hal lainnya perlu adanya kejelasan akan standar pelaksanaannya. Sehingga dengan kejelasan 
tersebut dapat menjadikan semua berjalan sesuai dengan aturan yang berlaku. Seperti halnya pada Kemendagri, standar pelaksanaan berbeda antar Ditjen-nya. Jelas tergambarkan bahwa setiap unit atau kelompok kerja pada sebuah organisasi berbeda pemberlakuan untuk setiap pelimpahan wewenang akan peningkatan kinerja terutama yang merujuk pada perspejtif gender. Perbedaan seperti ini yang menjadi sebuah "pekerjaan rumah" pada setiap pimpinan di setiap unit atau kelompok kerja masingmasing.

Jika menyikapi hal pelimpahan wewenang, pimpinan belum dapat mengakomodir semua potensi yang ada pada Ditjen Bangda Kemendagri. Namun, pemberian pelimpahan wewenang telah dilakukan dan dijalan sesuai dengan porsi dan kapasitas setiap ASN dengan memperhatikan tugas pokok dan fungsi masing ASN serta tentu juga memperhatikan kinerja yang merujuk pada perspektif gender. Pelaksanaan pelimpahan wewenang telah berjalan dengan baik sehingga dapat menjangkau semua tinghkatan pada Ditjen Bangda Kemendagri. Pelimpahan akan wewenang telah diakomodir dengan baik oleh para pimpinan sesuai dengan hierarki dan tanggungjawab yang menjadi tugas masingmasing ASN tersebut. Tujuan organisasi tentunya merupakan hal utama dalam setiap pekerjaan yang akan dilakukan oleh setiap individu. Oleh sebab itu perlu adanya kerjasama dan dukungan dari antar individu dalam pelaksanaan pekerjaan. Hal ini yang menjadi peran penting pimpinan dalam mengakomodir pelimpahan wewenang guna menunjang kinerja yang lebih baik lagi. Jelas terlihat keberagaman kerjasama antar ASN baik perempuan maupun lakilaki terjalin dengan baik. Hal tersebut yang dapat menjadi sebuah organisasi terutama organisasi yang tidak mengedepankan profit atau laba melainkan mengedepankan kepentingan publik serta menjaga efektivitas dan efisiensi dalam penyelesaian memerlukan sebuah kerjasam yang baik. Tentunya keberagaman yang timbul merupakan dari buah adanya kesenjangan antara komposisi tugas dengan sumber daya yang memadai. Hal tersebut menjadikan sebuah pokok pikiran yang harus diperhatikan oleh pimpinan Ditjen Bangda Kemendagri. Guna meminimalisir akan adanya kesenjangan yangdalam penyelesaian tugas dan wewenang Pimpinan Ditjen Bangda Kemendagri dapat melakukan bimbingan teknis (bimtek) kepada seluruh ASN. Dengan adanya Bimtek tersebut diharapkan dapat mendukung terselengaranya kerjasama antar individu dalam kelompok dan unit kerja, sehingga dengan adanya kerjasama yang solid tersebut dapat menuju organisasi yang lebih baik lagi

Direktorat Jenderal Bina Pembangunan Daerah Kementerian Dalam Negeri telah dengan tegas melaksanakan pemerataan dan kesetaraan gender. Kesetaraan dan keadailan tersebut teraktualisasi dengan adanya pemerataan tugas sesuai dengan kemampuan. Lebih jauh lagi kesetaraan juga telah dilakukan dengan hal memberikan peluang atau kesempatan kepada seluruh ASN untuk dapat proaktif mengembangkan potensi diri dan kemampuan sesuai dengan kapasitas masingmasing.

Masukan atas berbagai upaya yang layak dilakukan oleh Ditjen Bangda Kemendagri yaitu salah satunya adalah dengan meminimalkan kesenjangan pembagian tugas. Keberhasilan pelimpahan pemberian tugas dicerminkan dengan ketepatan pimpinan Ditjen Bangda Kemendagri dalam memberikan pelatihan dan ketrampilan serta ketepatan pelimpahan dalam tugas belajar bagi setiap ASN.

Bergeraknya roda organisasi dengan baik dicerminkan oleh ketepatan pimpinan memberikan porsi peningkatan kapasitas inteketual kepada setiap ASN tanpa membedakan gender atau jenis kelamin pada Ditjen Bangda Kemendagri. Tanpa melihat dari perspektif gender penepatan dalam pelimpahan tugas dilakukan dengan merata sesuai dengan kapasitas dan kemampuan dari setiap individu ASN tersebut. Mengkritisi pelimpahan tugas setiap ASN tentunya dilakukan dengan melakukan pemetaan terhadap kemampuan dan kapasitas setiap ASN di Ditjen Bangda Kemendagri. Pemetaan yang dimaksud adalah dengan melihat jenjang jabatan serta intelektualitas tanpa melihat perspektif gender dalam melaksanakan tugas tersebut. Penilaian hasil kerja khusus dalam menyikapi kinerja ASN berdasarkan perspektif Gender pada Ditjen Bina Pembangunan Daerah Kementerian Dalam Negeri yang dilakukan dengan berkesinambungan dan berjenjang guna meningkatkan kinerja setiap ASN. Hal tersebut diharapkan oleh setiap ASN dalam penyelasaian tugas serta wewenang yang diberikan.

Target dan sasaran yang hendak dicapai pada sebuah organisasi memiliki penilaian tersendiri. Hal ini yang menjadi perhatian khusus bagi Pimpinan Ditjen Bangda Kemendagri yang diharapkan dapat menjadi sebuah tolak ukur dalam melakukan penilaian serta tentunya dengan mengacu pada ketentuan dan aturan yang telah diberlakukan. Penilaian kinerja yang dilakukan dalam konteks mandiri hanya terkait pada kinerja ASN Ditjen Bangda 
Kemendagri dipandang hanya perlu dilakukan pada saat waktu-waktu tertentu saja semisal saat akhir tahun atau perayaan kemerdekaan serta peringatan lainnya. Namun hal tersebut dipandang sebagai sesuatu yang layak untuk diterapkan setiap saat.

Penilaian kinerja secara berkala dan dilaksanakan untuk kalangan sendiri dipandang perlu guna meningkatkan kinerja ASN yang tidak memandang perspektif gender pada Ditjen Bangda Kemendagri. Sehingga dengan diadakannya penilaian pada kalangan sendiri tentunya disinyalir akan meningkatkan kinerja para ASN di Ditjen Bangda Kemendagri. Namun program yang diharapkan berjalan dengan baik tentunya perlu adanya keberlanjutan dari hasil penilaian tersebut. Hasil evaluasi yang dilakukan diharapkan dapat terus ditindak lanjuti oleh 135 pimpinan Ditjen Bangda Kemendagri. Tindak lanjut tersebut diharapkan dapat terus dilakukan karena diharapkan bisa membantu ASN tanpa memandang persfektip gender terus berkompetisi dalam dunia kerja. Dalam hal tersebut kinerja ASN dapat terdorong dengan adanya evaluasi kinerja mandiri pada Ditjen Bangda Kemendagri. Menjadi sebuah "pekerjaan rumah" yang besar bagi pimpinan serta seluruh ASN Ditjen Bangda Kemendagri untuk dapat memformulasikan konsep penilaian yang akan dikembangkan pada Ditjen Bangda Kemendagri, sehingga dengan tercipta formulasi konsep kinerja tersebut dapat memberikan sebuah stimulus bagi ASN untuk memiliki kinerja yang lebih baik tanpa memandang sudut pandang gender dengan kesamarataan tugas dan wewenang.

\section{Analisis Kendala Kinerja ASN Dalam Perspektif Gender Di Lingkungan Direktorat Jenderal Bina Pembangunan Daerah}

Menyikapi keadilan dan kesetaraan gender dalam dunia kerja, serta untuk meningkatkan kinerja ASN tanpa memandang perspektif gender, tentunya tidak sebaik yang dibayangkan melainkan terdapat beberapa kendala yang disinyalir dapat timbul. Atas sudut pandang ini penulis mencoba menguraikan kendala yang dihadapi Ditjen Bangda Kemendagri, yaitu:

\section{Analisis Kendala Motivasi}

Motivasi yang disinyalir menjadi sebuah kendala untuk meningkatkan kinerja di Direktorat Jenderal Bina Pembangunan Daerah Kementerian Dalam Negeri agar menjadi perhatian khusus kepada para Pimpinan Ditjen Bangda Kemendagri utnuk dapat memperhatikan potensi dari setiap ASN. Karena dengan adanya perhatian dari pimpinan diharapkan setiap ASN memiliki motivasi berlebih. Serta yang tak kalah pentingnya adalah Ditjen Bangda Kemendagri kerjasama tim yang kurang dalam bekerja dan rasa memiliki dalam membangun organisasi yang solid pada Ditjen Bangda Kemendagri.

Kendala yang kerap timbul berupa masih adanya memandang perempuan sebelah mata pada Ditjen Bangda Kemendagri, seperti yang diutarakan diatas bahwa kendala yang sering dirasakan yaitu peluang kesempatan untuk berkembang tanpa adanya campur tangan pihak lain masih sebuah kendala tersendiri dalam melakukan persaingan kinerja yang lebih baik lagi antar ASN, sehingga belum optimalnya pencapaian kinerja dalam perspektif gender. Kecondongan penilaian pada laki-laki dirasakan sangat menonjol di Ditjen 137 Bangda Kemendagri. Hal tersebut disinyalir diawali dengan penilaian yang dilakukan dengan cara subjektif baik pada gender tertentu atau jenjang pendidikan tertntu. Subjektifitas penilaian ini cenderung menjadikan ASN motivasi tinggi menjadi bermasalah, terutama ASN perempuan yang meiliki peran ganda. Peran ganda ASN Perempuan yang menjadikan keterbatasan waktu dan kesempatan untuk dapat memiliki kinerja yang baik secara psikologi sangat menghambat karena mendasari pemikiran menjadi terbelah. Disisi lain ASN Perempuan menjadi seorang pegawai namun disisi lain menjadi seorang ibu rumah tangga. Hal ini belum bisa lepas dari pola pikir setiap ASN Perempuan yang ingin bekerja secara profesional tetap fokus pada tugas disaat jam kerja berlangsung. Sikap profesional ini sejatinya ingin ditunjukkan oleh setiap ASN perempuan

Kendala pembuktian diri untuk terus berkembang dan sama dalam penyelesaian tugas 138 nampak mendaji kesulitan tersendiri bagi ASN perempuan. Hal yang kerap terjadi pada ASN perempuan ini seiring dengan menruncingnya anggapan bahwa wanita dalah kaum yang lemah sehingga perlu dilakukan pertolongan ternaman pekat pada mindset ASN laki-laki. Terungkap bahwa sebagai seorang perempuan motivasi untuk dapat memimpin menjadi sebuah kendala tersendiri yang diungkapkan oleh informan. Kesulitan secara psikologis yang dirasakan oleh informan untuk menjadi seorang pemimpim dari kalangan perempuan menjadi sebuah dilema untuk dapat mempengaruhi atau mereka sebagai yang dipimpin menjadi pengikut. Konteks lebih luas terjabarkan bahwa hambatan tersebut terbentuk atas dua faktor yakni eksternal dan internal 
dalam memproyeksikan kinerja yang lebih baik. 140 Faktor eksternal datang dari lingkungan sekitar yang masih butuh dukungan dari diri ASN tersebut sehingga konsesntrasi terpecah menjadi dua untuk waktu penyelesaiaannya. Sedang untuk faktor internal yang datang dalam diri ASN masih dapat ditanggulangi dengan baik oleh setiap ASN sehingga faktor eksternallah yang menjadi kesulitan tersendiri bagi ASN untuk menyikapinya

Penyelesaian terhadap kendala yang timbul dapat diminimalkan oleh setiap diri ASN dengan mindset kepercayaan diri yang besar. Kepercayaan diri bahwa setiap ASN mampu menyelesaikan setiap kendala yang timbul guna membangkitkan motivasi ASN perempuan untuk terus membuktikan diri bahwa mereka mampu bersaing dengan ASN laki-laki. Kendala yang timbul karena motivasi ASN yang kurang dapat diakibatkan dari faktor internal dan eksternal. Sebagai bahan pertimbangan bahwa faktor eksternal yaitu dukungan dari pimpinan, pembagian proporsi tugas pekerjaan yang tidak seimbang, serta masih adanya anggapan bahwa ASN perempuan belum dalam atau layak memimpin organisasi besar seperti Ditjen Bangda Kemendagri. Oleh sebab itu perlu adanya dukungan dari semua pihak dan elemen organisasi untuk tersu dapat meingkatkan motivasi ASN perempuan guna mendukung peningkatan kinerja ASN dalam perspektif gender.

\section{Analisis Kendala Komptensi}

Kompetensi yang digaungkan sebagai kemampuan, keahlian serta keterampilan baik secara manajerial maupun administratif dengan keahlian khusus atau umum menjadi sebuah kendala tersendiri yang kerap muncul pada diri ASN. Degradasi motivasi menghantui ASN perempuan untuk berkembang. Hal ini ditengarai karena adanya kondisi tempat kerja dirasakan kurang nyaman. Kurang nyaman dalam hal perkembangan karir, perkembangan kemampuan serta keahlian ASN perempuan dalam meniti kinerja yang lebih baik lagi. ASN perempuan masih berbenturan dengan anggapan dasar bahwa perempuan merupakan mahluk yang lemah, sehingga pergerakan mereka perlu dibantu dan ditolong oleh laki-laki. Oleh sebab itu untuk kedepannya ASN perempuan perlu menepis anggapan tersebut guna menyokong untuk mendapatkan kesempatan kinerja yang lebih baik lagi. Kembali terlihat bahwa pemerataan kesempatan berkembang bagi ASN perempuan di Ditjen Bangda Kemndagri yang masih menjadi dilema untuk membuktikan kinerja yang baik. Permasalahan tersebut diharapkan untuk dapat di minimalkan. Tuntutan akan kreatifitas dan inovasi dalam bekerja terus digalakkan oleh segenap elemen Ditjen Bangda Kemendagri. Peningkatan kompetensi diri ASN perempuan tersebut yang menjadi sebuah kendala masih sering muncul dalam penyelesaian tugas kerja pada Ditjen Bangda Kemendagri. keterbatasan akan pengembangan diri dari setiap ASN nampak menjadi sebuah kendala atau permasalahan yang perlu penyelesaian jalan keluar yang tegas dari Pimpinan Ditjen Bangda Kemendagri. Selain keterbatasan pengembangan diri tersebut, terdapat permasalahan lain yang muncul. Iklim kerja yang kurang kondusif muncul sebagai faktor kendala dalam memandang kinerja ASN terutama perempuan. Dimana masih adanya ketidaknyamanan dalam bekerja karena sikap pimpinan yang tidak melakukan penyesuaian atau kesamarataan dalam memandang potensi dan keahlian setiap ASN terutama dan utama adalah ASN Ditjen Bangda Kemendagri perempuan. Sehingga penurunan motivasi atas hal tersebut kerap terjadi pada ASN perempuan yang masih dianggap sebelah mata oleh rekan kerja dan pimpinan pada Ditjen Bangda Kemendagri.

Kendala akan kompetensi pada ASN terutama perempuan kerap muncul pada organisasi Ditjen Bangda Kemenagri. Kendala ini muncul disinyalir dari berbagai banyak faktor terutama adalah faktor internal dan eksternal. Dimana faktor interal disebabkan oleh adanya kurang kepercayaan diri dari masingmasing ASN 144 perempuan untuk dapat berkembang dan mengembangkan diri didalam dan luar organisasi Ditjen Bangda Kemendagri. Sedangkan faktor eksternal yang kerap terlihat adalah masih adanya pandangan sebelah mata akan kemampuan ASN perempuan untuk dapat menyelesaikan tugas sendiri sehingga dipandang masih membutuhkan bantuan lebih dari ASN yang lainnya (terutama laki-laki). selain itu faktor dukungan pimpinan Ditjen Bangda Kemendagri yang minim masih menjadi kendala yang membutuhkan jalan keluar lebih kongkrit lagi agar dapat mengangkat moral dan motivasi ASN perempuan untuk dapat bekerja dan menghasilkan kinerja yang lebih baik lagi.

\section{Analisis Kendala Regulasi}

Regulasi atau aturan yang seyogyanya menudukung serta menjadi payung hukum untuk para ASN dapat bekerja dengan tenang dan nyaman merupakan menjadi dasar dan landasan para pimpinan serta ASN untuk dapat menggerakan roda kehidupan organisasi lebih kuat dan baik lagi. Namun, secara praktisi 
regulasi yang teleh ada belum sepenuhnya diterapkan dan dijalankan oleh organisasi Ditjen Bangda Kemendagri. Pembebanan yang tidak sesuai prosi antara ASN laki-laki dengan yang perempuan mencuat menjadi sebuah kendala yang harus dihadapi oleh Pimpinan Ditjen Bangda Kemndagri. Hal tersebut muncul karena adanya anggapan bahwa ASN perempuan dalam keadaan yang lemah serta tidak perlu terlalu banyak diberikan porsi pekerjaan lebih besar dari laki-laki.

Penekanan pada posisi yang ada pada lingkungan Ditjen Bangda Kemendagri masih merupakan sebuah fenomena permasalahan tersendiri yang kerap muncul. Karena masih adanya keberpihakan pemilihan jabatan tertentu yang harus isi oleh laki-laki. Hal ini yang menjadi salah satu pemicu kendala penerapan yang kuat dari regulasi yang ada. Harapan akan hasil dari penegakan regulasi yang jelas berupa pengahargaan dan hukuman masih menjadi kendala yang perlu diperhatikan oleh seluruh elemen Ditjen Bangda Kemendagri. Karena dengan diberlakukannya reward and punishment diharapkan tidak adalagi kendala dalam menerapkan semua regulasi yang ada. Melihat dari sudut pandang lain bahwa pelimpahan wewenang pekerjaan yang belum merata kepada ASN Perempuan menjadi kendala sebagai ASN Perempuan untuk menunjukkan kinerja yang baik. Karena dalam sudut pandang proporsi yang kurang berimbang ASN perempuan jauh tertinggal. Oleh sebab itu ASN perempuan pada Ditjen Bangda Kemndagri dianggap masih memiliki kekurangan dalam proporsi kinerja.

Hal yang telah berlajan dengan disinyalir yang masih belum optimal dalam penerapan regulasi yang ada yaitu sangsi yang lemah bagi ASN yang melanggar. Karena dengan kelemahan tersebut tercermin sikap dan serta komitmen Pimpinan Ditjen Bangda Kemendagri untuk terus menerapkan regulasi yang telah dibuat dan diterapkan dengan baik.

\section{Analisis Kendala Budaya Organisasi}

Budaya organisasi yang berkembang pada Ditjen Bangda Kemendagri tentunya dapat dijadikan sebuah rujukan dalam penerapan kinerja yang baik dalam memandang perspektif gender. Namun budaya organisasi yang berkembang tentunya tidak berjalan tanpa kendala melainkan pasti ada kendala yang membayangi perjalanan organisasi tersebut. Anggapan bahwa ASN perempuan tidak dapat bekerja secara optimal tersebut yang menjadi salah satu pemicu kerap terjadinya kendala dalam mengembangkan budaya organisai yang kondusif. Karena statement tersebut sangat sensitif didengar oleh para ASN Perempuan yang merasa diri mereka dapat dan mampu bersaing kepada pada ASN Laki-laki. Kemapuan untuk dapat mengelola sumber daya yang ada pada organisasi 148 menjadi tolak ukur perjalanan organisasi menuju capaian sasaran tujuan yang telah ditentukan oleh para anggota tersebut. Pemberian porsi yang seimbang ditentukan oleh pimpinan organisasi yang dapat bersifat bijak dalam mendistribusikan tugas dan wewenang kepada seluruh ASN yang terlibat

Pemahaman akan budaya organisasi belum sepenuhnya dipahami oleh ASN. Sehingga kendala ini muncul sebagai permasalahan organisasi menuju tujuan yang telah ditetapkan. Budaya organisasi yang berkambang sejati mengikuti Rencana Strategis yang telah ditetapkan bersama antara pimpinan dan anggota organisasi telah sepatutnya terus dicanangkanAdanya statement yang timbul dari budaya yang berkembang di Ditjen Bangda Kemendagri yaitu bahwa pekerja perempuan tidak dapat lembur serta belum optimalnya pemberian penghargaan pada ASN Perempuan untuk dapat memberikan pada kedudukan pimpinan dirasakan masih kurang dan belum optimal. Sehingga pimpinan dengan kewibawaan dan kebijaksanaan perlu memperhatikan akan permasalahan ini. Kurangnya kesempatan bagi ASN perempuan untuk duduk sebagai pimpinan yang diharapkan dapat memberikan kebijakan perubahan dalam bekerja masih dirasakan kurang oleh para ASN. Masih berkembangnya pola pikir akan lemahnya kaum wanita dalam menyelesaikan tugas menjadi kendala yang hampir setiap saat berkembang pada budaya organisasi Ditjen Bangda Kemendagri sehingga kendala ini sulit untuk dapat dihapuskan bahkan hampir sukar hilang. Stigmatisasi akan lemahnya perempuan dalam dunia kerja perlu dihapusakan dari pola pkir semua pegawai atau ASN di Ditjen Bangda Kemendagri. Sehingga dengan hilangnya stigmasisasi tersebut diharapkan dapat menjadikan pegawai atau ASN baik perempuan maupun laki-laki dapat bersaing untuk pengembangan diri 150 secara profesional dan proporsional sesuai dengan aturan dan regulasi yang berlaku. Dengan tidak adanya stigmatisasi tersebut maka diharapkan dapat menjadikan roda organisasi Ditjen Bangda Kemendagri berjalan dengan baik seperti yang diharapkan

Secara garis besar permasalahan pemerataan di Ditjen Bangda Kemendagri dirasakan sudah terwakili sehingga jalan keluar dalam kendala tersebut telah terjawab yakni dengan keterwakilan pimpinan Ditjen Bangda 
Kemendagri Pradita P Utami, M.Simpuk oleh seorang perempuan. Dimana dalam hal ini keterwakilan perempuan pada pucuk pimpinan telah terekomendasikan. Kendala yang kerap timbul dalam menyikapi permasalah kinerja gender dalam penelitian ini timbul seperti yang dilontarkan informan yaitu kendala akan komptensi setiap ASN untuk dapat bersaing dengan ASN lainnya dalam hal kinerja yang lebih baik lagi, serta permasalahan kesejangan untuk pengembangan diri pada setiap ASN dianggap belum meratanya pemberian tugas belajar sebagai salah satu wadah ASN untuk dapat mengembangakn diri, potensi diri serta bakat dan kemampuan guna menunjang kinerja inividu yang lebih baik sehingga dapat menjadikan organisasi juga lebih baik lagi.

\section{KESIMPULAN DAN SARAN Kesimpulan}

Berdasarkan hasil penelitian serta analisis pembahasan penulis mengajukan kesimpulan hasil penelitian sesuai dengan rumusan masalah yang diajukan yaitu:

a. Kinerja Aparatur Sipil Negara dalam Perspektif Gender di Direktorat Jenderal Bina Pembangunan Daerah yang dianalis dari empat sudut pandang yakni dapat disimpulkan sebagai berikut:

b. Dilihat berdasarkan sudut padang motivasi Aparatur Sipil Negara Direktorat Bina Pembangunan Daerah Kementerian Dalam Negeri masih rendah karena masih belum terbuka lebar untuk ASN perempuan diberikan kesempatan dalam memberikan kontribusi yang lebih bagi ASN perempuan berupa sumbang pikiran dan tenaga dengan setiap pengambilan keputusan

c. Dilihat berdasarkan sudut padang kompetensi Aparatur Sipil Negara Direktorat Bina Pembangunan Daerah Kementerian Dalam Negeri masih belum adanya pemerataan dalam memberikan peluang untuk dapat mengembangkan potensi serta kemampuan diri untuk meningkatkan kinerja yang lebih baik lagi

d. Dilihat berdasarkan sudut padang regulasi yang mengatur kinerja Aparatur Sipil Negara Direktorat Bina Pembangunan Daerah Kementerian Dalam Negeri penerapan yang telah maksimal dilakukan oleh Direktorat Bina Pembangunan Daerah Kementerian Dalam Negeri, sehingga setiap ASN tanpa memandang perspektif gender mempunyai kesadaran akan terus mantaati dan mematuhi regulasi tersebut

e. Dilihat berdasarkan sudut padang budaya organisasi yang berkembang dalam mendukung kinerja Aparatur Sipil Negara Direktorat Bina Pembangunan Daerah Kementerian Dalam Negeri telah berkembang dengan baik seiring dengan bijaknya pimpinan Direktorat Bina Pembangunan Daerah Kementerian Dalam Negeri dalam memberikan tugas dan wewenang sesuai denga porsi dan proporsi bagi ASN baik perempuan maupun laki-laki

Kendala timbul pada saat mendukung kinerja ASN dalam Perspektif gender di lingkungan Direktorat Jenderal Bina Pembangunan Daerah

a. Kendala motivasi kurangnya perhatian pimpinan terhadap ASN yang memiliki potensi untuk dapat dipromosikan memiliki jabatan atau kedudukan pada Direktorat Jenderal Bina Pembangunan Daerah Kementerian Dalam Negeri

b. Kendala kompetensi adanya ketidaknyamanan ASN perempuan dalam bekerja, sehingga segala kemampuan dan keahlian yang dimiliki disembunyikan tidak sepenuhnya diaplikasikan dalam dunia kerja yaitu Direktorat Jenderal Bina Pembangunan Daerah Kementerian Dalam Negeri

c. Kendala regulasi Pembebanan yang tidak sesuai prosi antara ASN laki-laki dengan yang perempuan mencuat menjadi sebuah kendala yang harus dihadapi oleh Pimpinan Ditjen Bangda Kemndagri. Hal tersebut muncul karena adanya anggapan bahwa ASN perempuan dalam keadaan yang lemah serta tidak perlu terlalu banyak diberikan porsi pekerjaan lebih besar dari laki-laki

d. Kendala budaya organisasi Anggapan bahwa ASN perempuan tidak dapat bekerja secara optimal tersebut yang menjadi salah satu pemicu kerap terjadinya kendala dalam mengembangkan budaya organisai yang kondusif. Karena statement tersebut sangat sensitif didengar oleh para ASN Perempuan yang merasa diri mereka dapat dan mampu bersaing kepada pada ASN Laki-laki 


\section{Saran}

Berdasarkan kesimpulan yang diperoleh, maka saran-saran yang disampaikan adalah sebagai berikut:

\section{Saran Praktis}

1. Disarankan kepada Pimpinan Direktrat Jenderal Bina Pembangunan Daerah Kementerian Dalam Negeri untuk dapat meningkatkan kinerja ASN tanpa melihat perspektif gender dengan memberikan pengembangan diri melalui tugas belajar atau pelatihan manajerial dan pelatihan administrasi

2. Disarankan kepada Pimpinan Direktorat Jenderal Bina Pembangunan Daerah Kementerian Dalam Negeri untuk dapat meningkatkan kinerja ASN tanpa melihat perspektif gender dengan membuka pintu peluang kepada seluruh ASN yang memiliki potensi untuk menduduki sebuah jabatan tertentu dengan aturan dan tata cara yang telah ditentukan oleh peraturan yang berlaku

3. Disarankan kepada Pimpinan Direktorat Jenderal Bina Pembangunan Daerah Kementerian Dalam Negeri untuk dapat meningkatkan kinerja ASN tanpa melihat perspektif gender dengan tegas menerapkan dan mengaktualisakan semua aturan dan regulasi yang ada pada tubuh Direktorat Jenderal Bina Pembangunan Daerah Kementerian Dalam Negeri

4. Disarankan kepada Pimpinan Direktorat Jenderal Bina Pembangunan Daerah Kementerian Dalam Negeri untuk dapat meningkatkan kinerja ASN tanpa melihat perspektif gender yaitu dengan menciptakan suasana kerja yang kondusif seperti adanya doa bersama sebelum melakukan pekerjaan atau makan siang bersama antar pimpinan dan bawahan yang dilakukan seminggu sekali atau dua kali.

\section{Saran Teoritis}

Memandang konteks yang lebih luas lagi penulis memberikan saran teoritis yaitu:

1. Kepada Rektor Institut Pemerintahan Dalam Negeri (IPDN) kiranya hasil penelitian ini dapat dijadikan rujukan sebagai pengembangan terapan Ilmu Pemerintahan terutama pada program pascasarjana strata dua IPDN, sehingga khasanah keilmuan pada IPDN mencada berwarna dan beragam

2. Kepada peneliti selanjutnya, karena konteks metode penelitian dengan menggunakan metode kualitatif, kiranya pada peneliti selanjutnya dapat memberikan keberagaman metode penlitian dengan mengangkat dari sudut padang kuantitatif dengan objek yang hampir sama yaitu Kinerja dalam Perspektif Gender

\section{DAFTAR PUSTAKA}

A.A. Anwar Prabu Mangkunegara ,2000, Manajemen Sumber Daya Manusia, Bandung. PT, Remaja Rosdakarya.

Ahmad S Ruky. 2002. Sistem Manajemen Kinerja. PT Gramedia Pustaka Utama. Jakarta.

Ambar Teguh Sulistiyani dan Rosidah, 2003, Manajemen Sumber Daya Manusia, Graha Ilmu: Yogyakarta.

Anderson, Gordon, C, (1993). Managing Performance Appraisal System. Blackwell Publishers, UK.

Armstrong, M. and Baron, A. 1998. Performance Management - The New Realities. London: Institute of Personnel and Development

Cahayani, Ati. 2005. Strategi dan Kebijakan Manajemen Sumber Daya Manusia. Penerbit Indeks, Jakarta.

C.F. Strong. 1960, Modern Political Constituion, Sidgwick \& Jackson Ltd., London

Dessler Gary, 2009. Manajemen Sumber Daya Manusia, Edisi Kesepuluh. Jilid Dua. Jakarta: PT Indeks

Dessler, Gary. 1997. Management Sumber Daya Manusia. Terjemahan. Benyamin Molan. Edisi Bahasa Indonesia. PT Prenhallind. Jakarta.

Ermaya Suradinata, 1998, Manajemen Pemerintahan dan Otonomi Daerah, Bandung : Ramadan.

Ermaya, Suradinata. 1996. The Relationship Between Leadership Style and Employee Performance. Singaporean Journal of business Economics, and Management Studies. Vol. 2, No. 5, pp. 51-53.

Gomes, Faustino Cardoso, 2003, Manajemen Sumber Daya Manusia, Yogyakarta : Andi.

H.A Brasz. 1975, Inleiding tot de Bestuurswetenschap, Vuga Boekerij Handayaningrat, Suwarno. 1994. 
Administrasi Pemerintahan Dalam Pembangunan Nasional. Jakarta: PT. Gunung Agung. 158

Hasibuan, Malayu. 2012. Manajemen Sumber Daya manusia. Jakarta: PT Bumi Aksara.

Ilyas, Yaslis, 2001. Kineraja : Teori, Penilaian dan Penelitian. FKM UI, Jakarta

Mathis Robert, Jackson John. 2002. Manajemen Sumber Daya Manusia. Jakarta : Salemba empat

Ndraha, Taliziduhu. 1997. Metodologi Ilmu Pemerintahan. Jakarta: Rineka Cipta 2000. Kybernologi dan Kepamongprajaan, cet 1, Banten : Sirao Credentia Center.

Ndraha, Taliziduhu. 2003. Kybernology (Ilmu Pemerintahan Baru) Jilid 1. Jakarta : PT Rineka Cipta.

Nugraha, Safri. 2007. et al, Hukum Administrasi Negara, cet Kesatu edisi revisi (Depok:CLGS-FHUI), hal 180.

P. Siagian, Sondang.2002. Kepemimpinan Organisasi \& Perilaku Administrasi, Jakarta: Penerbit Gunung Agung

Pigors, Paul., \& Charles A. Myers. 1961. Personal Administration. New York : Mc Graw Hill Book Company, Inc.

Prawirosentono, Suyadi. 1999. Kebijakan Kinerja Karyawan. Yogyakarta : BPFE

Prawirosentono.S, 1999. Manajemen Sumber Daya Manausia, Kebijakan Kinerja Karyawan. Yogyakarta : BPFE.

R. Mac Iver. 1947, The Web of Government, The Mac Millan Company Ltd., New York

Rivai, Veithzal dan Basri. 2005. Performence Appraisal: Sistem yang Tepat untuk Menilai Kinerja Karyawan dan
Meningkatkan Daya Saing Perusahaan. Jakarta: Raja Gravindo Persada.

Robbins, S. 2008. Perilaku Organisasi, Jilid I dan II, alih Bahasa : Hadyana Pujaatmaja. Jakarta: Prenhallindo.

Robbins, Stephen P. 2001. Perilaku Organisasi: Konsep, Kontroversi, Aplikasi, Jilid 1, Edisi 8, Prenhallindo, Jakarta.

S.P. Siagian. 1978. Manajemen, Yogyakarta: Liberty

Sagala, Syaiful. (2007). Konsep dan Makna Pembelajaran. Bandung: CV. ALFABETA159

Sedarmayanti, 2004, Manajemen Sumber Daya Manusia, Liberty, Yogyakarta.

Siagian, P. Sondang. 2002. Kepemimpinan Organisasi \& Perilaku Administrasi. Jakarta: Penerbit Gunung Agung.

Simanjuntak, Payaman J. 2005. Manajemen dan Evaluasi Kinerja. Jakarta: FE UI

Sinambela, LijanPoltak. 2006. Reformasi Pelayanan Publik:Teori, Kebijakan, dan Implementasi. Jakarta: PT. BumiAksara.

Steers, R.M and Porter, R. W (1983). Motivation and Work Behavior. New York: Mc Graw Hill.

Sutermeister, R. A. (1976). People and Productivity. Third Edition. New York: Mc.Graw Hill Book Company.

Tjokroamidjojo, Bintoro. 1995. Pengantar Administrasi Pembangunan. LP3S. Jakarta

U. Rosenthal. 1978, Openbaar Bestuur, Samson HD., Jeenk Willink, Alphen aan den Rijn, Leiden Werther, William B. \& Keith Davis. 1996. Human Resources And Personal Management.Edisi kelima. New York: McGraw-Hill. 